\title{
Pussy Riot at the Crossroads of Politics and Faith Today
}

\author{
Matthew Del Nevo \\ Catholic Institute of Sydney
}

\begin{abstract}
Moscow-based Feminist Punk performers Pussy Riot challenged the millennial patriarchal Russian State-Church Religio-Political control on freedom in arts and suppression of women. Woman is still the other of this Church-State totalism, outside. The event is extremely small but the symbolism enormous of an intrinsic lack and its insane compensations. Philosopher Žižek sees the significance of what Pussy Riot represent for contemporary global capitalism, represented by the American dollar and Wall Street. Performer Madonna sees the difference between America, where she has been able to express herself and says that anyone can, and other parts of the world, namely Russia, where this is not possible. Although Edward Snowdon found sanctuary in Russia from America, so perhaps Žižek is right.
\end{abstract}

Keywords: Pussy Riot, feminine, protest, reform, patriarchal orthodoxy, patriarchal politics, Žižek

In Christianity, the idea of spiritual order acquires a yet wider and more profound significance. It is based upon the belief in a divine society which transcends all states and cultures and is the final goal of humanity. As a modern, Thomist has written,

The human personality is not entirely contained in political society; it belongs above all by its innermost and truest being, by its spiritual element, to another and more perfect society, to the universality of being, the world-whole which includes the living infinite, God himself, as its Universal Good and Sovereign Head; and political society, however wide and numerous it may be, is but a minute section of this immense and innumerable Republic, this city of God of which St. Augustine and St. Thomas speak. ${ }^{1}$ (Bésiade 1923, 334)

This society exists in the nature of things as "the republic of all men under the law of God,"2 although the actual disorder of human nature prevents its effective realisation by man. ${ }^{3}$

Today we have faith in politics. There is faith in God. There is faith in religion. There is religious faith in politics. And there is faith in something else (none of the above).

Faith in the ordinary sense of the word means a fullness of experience beyond assertions, by which alone we have a genuine grasp of reality. ${ }^{4}$ At the psychological level, faith then is allied with intuition of this, and growth of faith with growth of intuition. ${ }^{5}$

The arrest of members of Pussy Riot that followed their insurgence into a Russian holy place was a small event that the news magnified and that went global, or as they said, viral. It reverberated round the world. It was not just the event of what happened, but what it symbolized. It had to do with faith in religion because they were accused of desecrating a holy place, and it had to do with politics because the state got dragged into it. It had to do with faith because there is faith on all sides, only faith in different things and different kinds of faith.

Matthew Del Nevo, associate professor, Department of Philosophy, Catholic Institute of Sydney, Australia; main research field: Social Critical Theory/Aesthetics. Email: mdelnevo@cis.catholic.edu.au. 
The Pussy Riot incident raised issues about the relation of church and state, or symbolically, religious, and secular spheres, more precisely, how faith in religion, faith in politics, religious faith in politics, and faith in something else, all mesh. Naturally it is incongruous.

So to the facts of the matter...

Pussy Riot is a Moscow based feminist punk collective. Punk is both a rock music style and youth attitude. As music, one member of the collective puts it: "You don't have to sing very well. It's punk. You just scream a lot." As attitude it is anti-establishment. Punk dates back to the 1970s and the Ramones in New York and the Sex Pistols in London.

On February 21st, 2012, some members of Pussy Riot entered the Cathedral of Christ the Saviour, the major holy site in Moscow, the largest Cathedral in Russia, got up on the altar; they signed themselves with the cross, and ripped into a rendition of their track, "Punk Prayer-Mother of God, Chase Putin Away!” Pussy Riot regarded Putin as a dictator and the Russian Orthodox church as religiously legitimating the regime. Putin was used to being disliked but Russian Orthodoxy, which survived underground for 50 years during the Communist era, was not used to charges of illegitimacy and could not swallow them. This major supporter of Putin pushed for punishment.

Essentially Pussy Riot are performance artists. In an interview with a Russian popular magazine, a member of the Collective described their two-minute concerts as performance art, creating images of "pure protest, saying: Super heroes in balaclavas and acid bright tights seize public space in Moscow."7

As James Brooke from Voice of America (who lives in Russia) wrote in 2012: "In the old days (five years ago), Pussy Riot would have been a dead-end garage band, playing for friends in an abandoned warehouse. But now that half of Russia is online, their video performances are going viral, scoring hundreds of thousands of views. In six months, Pussy Riot has become a household name across Russia” (James Brooke 2012). ${ }^{8}$

Three members of the collective, Nadezhda "Nadya" Tolokonnikova, Maria "Masha" Alyokhina, and Yekaterina "Katya" Samutsevich were arrested in March of 2012 for "hooliganism motivated by religious hatred" and charged. Two other performers were not caught and escaped out of Russia by all reports. Nadya and Maria were sentenced to two years in prison in Siberia and held in separate prisons there. They were released from prison two months early, after serving 21 months of their sentence, in December of 2013, because of international pressure as the world looked toward the upcoming Russian hosted Winter Olympics in Sochi. Pressure came from Amnesty International who regarded Nadya and Maria as prisoners of conscience, and from other human rights groups and prominent arts celebrities like Madonna, Lady Gaga and Yoko Ono, but also revered figures like Aun San Suu Kyi the Burmese human rights activist and Nobel Peace Prize winner.

$<$ https://www.youtube.com/watch?v=3Pc3HSXM9VE $>$.

Pussy Riot including Nadya and Maria tried to perform another song at the Sochi Olympics but were whipped by Cossacks and forced to stop. The photos and videos of the young girls being lashed by Cossack troopers whizzed round the world news services and went viral on the internet.

Coming back to the act in the Cathedral, from the Orthodox point of view, it was a sacrilegious act. In that sense, it was a religious offence of the highest order.

The lyrics of the song "A Punk Prayer" indicate what is in the mind of the young women.

The chorus is an invocation to the Virgin Mary and takes the form of supplication: 
Virgin Mary, Mother of God, Banish Putin

Banish Putin, Banish Putin!

The chorus changes to:

Virgin Mary, Mother of God

Become a feminist, we pray thee

Become a feminist, we pray thee

From the Orthodox point of view, this kind of song is blasphemous.

From a more theoretical point of view, we might ask about the spirit in which these words are written and sung. Are they really praying? Do they really mean this prayer? Is what they pray what they really want? That is one question. From a more calculated point of view, assuming the answer is "Yes," we might ask then: What kind of feminist? Feminism is no longer a single cause. Feminism is plural. So even should the Virgin Mary wish to become a feminist, it would cause a lot of trouble among feminists themselves.

The issue seems to be this: We have charges of blasphemy and sacrilegious deeds on the Orthodox side and charges of sexism and rendering to Caesar the things that are God's on the girl's side and a question on both sides the boundaries of Orthodox culture and who and how it is represented.

There is a clash of beliefs about culture, religion, and politics.

In the film, footage to follow the viewer can see for themselves who are demonic: the girls or their religious accusers. Viewers can make up their own minds as to whether the girls have a point — made by their demonstration —about Orthodox Patriarchy or not. It is notable that the old woman who says their pious forebears paid for this Cathedral with penny donations out of their hard-earned savings (therefore the Pussy Riot demonstration is a callous insult to the dead) is reciting a myth and basically lying. Actually she would have lived almost the whole of her life under Communism when the Cathedral did not exist because Stalin had it totally demolished in 1931. It was rebuilt in the 1990s and consecrated under Putin in 2000.

The footage is something that it is illegal to upload and therefore I cannot provide a hyperlink. The documentary is made by HBO. The documentary makers are able to use footage filmed by the Russians themselves of the trial, and very professionally.

\section{Watch film}

From 29.30 The Orthodox mobilization

From 1.09 The girl's final word in court

There is not much point trying to describe this as the pictures tell a thousand words.

The world famous philosophers Slavoj Žižek and Nadya strike up a correspondence while she is in prison in Siberia, which has been published in 2014 by Verso entitled Comradely Greetings. ${ }^{9}$

Žižek writes: "What is so disturbing about Pussy Riot to the liberal gaze is that you make visible the hidden continuity between Stalinism and contemporary global capitalism” (2013). ${ }^{10}$ The connection here is missing a middle term, which we might call Leninism, as a cipher for the totally administered society and the corresponding rise of a new social class to affect this Leninst utopia: the manager. Pussy Riot is against Putin and the Church's legitimation of his regime and their hijacking of Orthodoxy per se to this end. They are against what Žižek calls Stalin, the totalitarian society. But Žižek draws a line of interpretation between this situation and this protest, such as Occupy Wall Street, against global capitalism. Žižek’s suggestion, as I 
understand it, is that capitalism dominates America and Russia under different forms of administration or Leninism. In the administered society, actual democracy must be limited. The press and television are made to depend financially for survival on advertising, which ensures that they only pander to the lowest common denominator, here the pressure on standards is downward in order to broaden the market. With the press and television dominated by the public relations industry, the engineering of consent within the political domain can be managed without violence or a police state. People obey willingly in the belief that the system is in their best interest and is the best of all possible worlds. Political involvement may mean something so small as a vote once every few years for one of the two parties that dominate power already. Only those with money are even in the race for power. This is in the Western system, which has been called post-political as politics itself has totally succumbed to commerce.

In the Eastern system, it is still political. This is one of the difficulties the west has with countries like Russia and China; politics still counts for something there. They still have a political society. Pussy Riot could not emerge out of America, because all protest is commodified and sold back to the protesters, so it just ends up a pop fad or fashion. So Pussy Riot comes west as something quite strange. What are these girls famous for we wonder? For us in the West, it can only seem like more Reality TV.

Žižek has drawn this line I have just referred to between Stalinism and global capitalism, to which I have added the third term: Lenin, and he comments:

For me, the true task of radical emancipatory movements is not just to shake things out of their complacent inertia, but to change the very co-ordinates of social reality so that, when things return to normal, there will be a new, more satisfying, “apollonian statics”. And, even more crucially, how does today’s global capitalism enter this scheme? ${ }^{11}(2014,48)$

The Deleuzian philosopher Brian Massumi tells how capitalism has already overcome the logic of totalising normality and adopted the logic of erratic excess: "The more varied, and even erratic, the better. Normality starts to lose its hold. The regularities start to loosen. This loosening is part of capitalism's dynamic" (2013). ${ }^{12}$

In this Deleuzian mess we are in according to Žižek, Pussy Riot’s demonstrations indicate a point of ethico-political stability:

The Pussy Riot performances cannot be reduced just to subversive provocations. Beneath the dynamics of their acts, there is the inner stability of a firm ethico-political attitude. In some deeper sense, it is today's society that is caught in a crazy capitalist dynamic with no inner sense and measure, and it is Pussy Riot that de facto provides a stable ethico-political point. The very existence of Pussy Riot tells thousands that opportunist cynicism is not the only option, that we are not totally disoriented, that there still is a common cause worth fighting for. ${ }^{13}(2013,62)$

Žižek's interpretation of Pussy Riot, of what they symbolize, seems to blur the distinction between Russia and America, putting the meaning of their antics down to the leftist fight against global capitalism, better represented by America than Russia. So Pussy Riot in this interpretation is shown to be as anti-American as they are anti-Putin. But perhaps there are parallels.

However, there is another interpretation which draws a distinction between the Russian system and the American system. This view focuses on freedom to express yourself. In America one can express oneself even against the government and one is free to do so. However, the point is that in Russia that is not the case and "democracy" means freedom to express yourself. This view is associated with public statements in Russia by the pop celebrity Madonna in July 2012 while Nadya and Masha were being tried. The film of Madonna taking off 
her leather jacket on an outdoor stage in front of a large number of audience in Moscow in 2012 where she toured, and showing that she had Free Pussy Riot daubed on her bare back went viral on the internet. She then gave a speech about how as an American she had been free to express herself even if her government did not agree with her, and she prayed for the day when everyone in every nation was free and able to express themselves whether or not the church or the government liked it. Pussy Riot appeared on stage with Madonna at the Amnesty International concert in Brooklyn, Feb., 2014.

In her speech to her audience, Madonna said that the people on stage with her were from every country, Africa, America, Russia, France; there are Christians, atheists, Jews, Muslims; we are black, white, gay, straight but we were one family and Madonna said this was how it should be. We were all human beings she said and this was the most important word, human being. Humanity is one family and every family member should be able to be themselves and be free to express themselves. This was democracy she said, and she did not take it for granted any more than she did not take for granted the support and love of her fans over so many years. For Madonna America may not be perfect, but it is the land of the free; it is a place where an Italian American girl from Bay City, Michigan can do her thing. The footage is here.

$<$ https://www.youtube.com/watch?v=lpNZN5rWIF0 $>$.

To finish off, there is a sense in Žižek's correspondence that the religious dimension is lost and becomes political, and the political not about Russia in particular but global capitalism. For Žižek, Pussy Riot symbolizes the outside of encompassing ideology. In Madonna's speech, taking her as symbolic of America, the engine of globalism and capitalism, the talk is of individual freedom of expression. For Madonna, Pussy Riot symbolizes a need for democracy. She makes it clear that the state has their view and the Church as theirs, but these are young girls and their point of view is not just to be trampled upon.

The girls themselves are extremely literate compared I think to educated girls their age in the consumer paradises we live in, in America and Australia. It is what happens when education sinks to business. Nadya writes to Žižek about freedom, but in relation to truth in a more religious sense or at least with more religious overtones. She quotes the Russian émigré philosopher Nicolai Berdyaev, interestingly, because as far as I am aware that Žižek never quotes Berdyaev in the entirety of his voluminous writings, although he quotes so many people. He might be better of reading Berdyaev than "his beloved Chesterton" as her refers to English story writer, journalist, and amateur theologian, G. K. Chesterton. This is from a young woman in prison in Siberia to Žižek, letter dated February 23rd, 2013:

Nikolai Berdyaev wrote in Self-Knowledge: "Truth as an object which intrudes itself and wields authority over me —an object in the name of which it is demanded that I should renounce freedom — is a figment: truth is no extraneous thing; it is the way and the life. Truth is spiritual conquest; it is known and through freedom." "Christianity itself is to me the embodiment of the revolt against the world and its laws and fashions." "From time to time a terrible thought crossed my mind: what if obsequious orthodoxy is right and I am wrong? In that case I am lost. But I have always been quick to cast this thought from me.” All statements that might have come from Pussy Riot just as easily as from Russia's greatest political philosopher. ${ }^{14}$ (Nadezhda Tolokonnikova and Slavoj Žižek 2014, 40-41)

This is the kind of Christianity we could do with more. 


\section{Notes}

1. T. Bésiade, La Justice générale, in Mélanges thiomistes, 1923, 334. Cited, Christopher Dawson, Christianity and the New Age (London: Sheed and Ward, 1931), 106.

2. St. Thomas, Sum. Th. i-ii, q. 100, a. 5 § Besiade, op. cit., 340. Dawson, ibid..

3. Christopher Dawson, Christianity and the New Age, 106.

4. Lou Andreas-Salomé, The Freud Journal, trans., Stanley A. Leavy (New York: Basic Books, 1964), 188.

5. Michael Eigen, Faith, (London: Karnac, 2014), XIII.

6. James Brooke (March 19, 2012). "Moscow Girl Band Sets Kremlin's Teeth on Edge." Voice of America. <http://blogs.voanews.com/russia-watch/2012/03/19/moscow-grrl-band-set-kremlins-teeth-on-edge/>.

7. Ibid.

8. Ibid..

9. Nadezhda Tolokonnikova and Slavoj Žižek, Comradely Greetings: The Prison Letters of Nadya and Slavoj (London and New York: Verso, 2014.

10. Slavoj to Nadya, Letter of January 2, 2013, ibid.,34.

11. Slavoj to Nadya, Letter of April 4, 2014, ibid., 48.

12. Ibid., 49.

13. Slavoj to Nadya, Letter of June 10, 2013, ibid., 62.

14. Ibid., 40-41.

\section{Works Cited}

Andreas-Salomé, Lou. The Freud Journal. Trans., Stanley A. Leavy. New York: Basic Books, 1964. 188.

Dawson, Christopher. Christianity and the New Age. London: Sheed and Ward, 1931.

Tolokonnikova, Nadezhda, and Slavoj, Žižek. Comradely Greetings: The Prison Letters of Nadya and Slavoj. London and New York: Verso, 2014. 